\title{
DESKRIPSI KOMPETENSI STRATEGIS MATEMATIS KELAS VII SMP NEGERI 1 PALOPO BERDASARKAN GENDER
}

\author{
Ni Putu Meli Wulandari ${ }^{1}$, Karmila ${ }^{2}$ \\ Universitas Cokroaminoto Palopo ${ }^{1,2}$ \\ niputumeliwulandari@gmail.com ${ }^{1}$, Karmila@uncp.ac.id ${ }^{2}$
}

\begin{abstract}
Abstrak
Penelitian ini adalah penelitian deskriptif kualitatif yang bertujuan untuk mendeskripsikan kompetensi strategis matematis kelas VII SMP Negeri 1 Palopo berdasarkan gendernya. Masalah dalam penelitian ini adalah kemampuan pemecahan masalah matematis siswa yang masih belum optimal. Subjek dalam penelitian ini adalah siswa kelas VII A SMP Negeri 1 Palopo yang berjumlahkan 2 orang, yaitu 1 subjek laki-laki dan 1 subjek perempuan. Instrumen penelitian adalah peneliti sendiri. Pada penelitian kali ini peneliti menggunakan instrumen yaitu; (1) tes kompetensi strategis matematis yang terdiri dari 3 soal uraian, dan (2) pedoman wawancara. Hasil dari tes kompetensi strategis matematis tersebut peniliti mendapatkan 2 subjek yang mendapatkan nilai tertingi yaitu 1 subjek laki - laki dan 1 subjek perempuan, kemudian kedua subjek tersebut dilakukan wawancara dari penelitian ini. Tes kompetensi strategis matematis mempunyai indicator yaitu; (1) merumuskan, (2) merepresentasikan, dan (3) memecahkan masalah. Hasil penelitian kali ini menunjukkan bahwa kompetensi strategis matematis pada subjek laki laki mampu memenuhi semua indicator pada soal nomor 1,2, dan 3 dan hasil penelitian kali ini juga menunjukkan bahwa kompetensi strategis matematis pada subjek perempuan mampu memenuhi indikator kompetensi strategis matematis pada soal nomor 1 dan 3 namun untuk soal nomor 2 subjek tidak mampu memenuhi dengan tepat indicator kompetensi strategis matematis.
\end{abstract}

Kata kunci: Kompetensi Strategis Matematis, berdasarkan gender.

\section{A. Pendahuluan}

Pendidikan merupakan hal yang sangat penting. Bukan saja sangat penting, bahkan pendidikan itu sama sekali tidak dapat dipisahkan dari kehidupan, baik dalam kehidupan keluarga, maupun dalam kehidupan Bangsa dan Negara. Maka dari itu, tidak berlebihan apabila ada istilah yang menyatakan tuntutlah ilmu sampai ke Negeri Cina, karena ilmu memang sangat penting dan berpengaruh dalam perkembangan bangsa. Pendidikan nasional adalah pendidikan yang berdasarkan Pancasila dan Undang-Undang Dasar Negara Republik Indonesia Tahun 1945 yang berakar pada nilai-nilai agama, kebudayaan nasional Indonesia dan tanggap 
terhadap tuntutan perubahan zaman.

Pembangunan pendidikan nasional adalah suatu usaha yang bertujuan untuk mewujudkan masyarakat Indonesia yang berkualitas, maju, mandiri, dan modern. Pembangunan pendidikan merupakan bagian penting dari upaya membangun karakter secara menyeluruh dan sungguh-sungguh untuk meningkatkan harkat dan martabat bangsa. Peran sekolah dalam mewujudkan belajar sepanjang hayat dilakukan melalui pengembangan kerjasama antara sekolah dengan lembaga keluarga, lembaga bisnis, lembaga lain dalam masyarakat dan dengan masyarakat sendiri. Di samping itu sekolah juga memiliki peranan sendiri. Dalam kaitannya dengan belajar sepanjang hayat, wajib belajar harus ditujukan pada provisi berbasis pengetahuan, dan pengembangan meta-skill untuk belajar. Oleh karena itu wajib belajar harus dapat memberikan pengatahuan umum untuk pengembangan kemampuan kognitif, afektif dan pemerolehan keterampilan belajar yang diperlukan untuk belajar sepanjang hayat (Sudarsana, 2016).

Menurut Sutarto Hadi (dalam Gazali, 2016) bahwa Pendidikan matematika di tanah air saat ini sedang mengalami perubahan paradigma. Terdapat kesadaran yang kuat, terutama di kalangan pengambil kebijakan, untuk memperbaharui pendidikan matematika. Tujuannya adalah agar pembelajaran matematika lebih bermakna bagi siswa dan dapat memberikan bekal kompetensi yang memadai. Belajar matematika, pada umumnya yang dianggap masalah bukanlah soal yang biasa dijumpai siswa.

Menurut Hudoyo (dalam Widjajanti, 2009) menyatakan bahwa soal/pertanyaan disebut masalah tergantung kepada pengetahuan yang dimiliki penjawab. Dapat terjadi bagi seseorang, pertanyaan itu dapat dijawab dengan menggunakan prosedur rutin baginya, namun bagi orang lain untuk menjawab pertanyaan tersebut memerlukan pengorganisasian pengetahuan yang telah dimiliki secara tidak rutin.

Kompetensi Strategis Matematis (KSM) dibangun dari tiga komponen kemampuan, yaitu merumuskan, mempresentasikan dan memecahkan masalah (Kilpatrick, Swafford, dan Findell, 2001). Tiga komponen ini merupakan aktivitas penting untuk mencapai kompetensi dalam kehidupan nyata. Pertama, kemampuan merumuskan adalah penting karena persoalan yang ada di dunia nyata merupakan 
persoalan yang belum dalam bentuk model matematika sehingga perlu adanya kecakapan untuk merumuskan dalam bentuk matematika. Kedua, kemampuan mempresentasikan adalah kecakapan untuk menghadirkan persoalan dalam bentuk tabel, gambar, ataupun diagram. Kemampuan ini memperlihatkan bentuk masalah yang lebih tergambarkan dan lebih konkrit sehingga tampak lebih mudah untuk dipahami dan diselesaikan. Ketiga, kemampuan pemecahan masalah adalah kecakapan menyelesaikan masalah yang tidak langsung diketahui apa yang harus dilakukan dan bagaimana cara melakukannya berdasarkan pengalaman. Pencapaian kemampuan kompetensi strategis matematis siswa sangat penting untuk menjadi manusia yang kompetitif (Hendrayana, 2015).

Berdasarkan hasil observasi pada pelaksanaan magang III bahwa siswa SMP Kelas VII sangat kurang terhadap kompetensi strategis matematis. Hal ini terjadi meskipun di sekolah siswa sering kali diberikan permasalahan khusus yang jelas untuk dipecahkan, tetapi di luar sekolah para siswa mengalami kesulitan untuk menjelaskan secara tepat permasalahan yang dihadapinya. Mereka perlu merumuskan masalah tersebut sehingga mereka dapat menggunakan matematika untuk memecahkannya. Akibatnya mereka membutuhkan pengalaman dan latihan dalam merumuskan masalah sebagaimana halnya dalam memecahkan masalah. Mereka harus mengetahui berbagai macam strategis pemecahan masalah serta mengetahui strategi mana yang memungkinkan berguna dalam menyelesaikan permasalahan khusus.

Manusia diciptakan menjadi dua jenis yaitu perempuan dan laki-laki yang menjadi dasar pembeda identitas manusia, secara fisik, kemampuan matematika, keunggulan, kelemahan, serta kemampuan sosialnya. Namun bukan berarti perempuan lebih unggul ataupun sebaliknya. Selama ini perbedaan jenis kelamin tersebut sebagai salah satu yang membedakan perkembangan kognitif manusia yang tentu saja sangat mempengaruhi bagaimana kemapuan berfikir seseorang.

Witelson menyatakan bahwa dalam gaya berfikir perempuan berbeda dari laki-laki karena ukuran dan bentuk otak yang berbeda dimana otak peempuan secara keseluruhan jauh lebih kecil dari otak laki-laki. Kartono menyatakan disbanding laki-laki umumnya perempuan jauh lebih akurat dan mendetail dalam 
memperhatikan sesuatu. Dengan berpendapat kemampuan verbal anak perempuan jauh lebih tinggi dari anak laki-laki.

Gender juga merupakan karakteristik yang membedakan peserta didik perempuan dan laki-laki dalam belajar khusunya dalam pembelajaran matematika. Gender merupakan atribut yang diasosiasikan dengan jenis kelamin seseorang termasuk peran, tingkah laku, preferensi yang menerangkan kelaki-lakian atau kewatiaan dalam konteks budaya tertentu (Hoang, 2008). Perbedaan gender dalam belajar matematika dapat menjadi faktor pembeda seseorang berfikir dan menentukan pemecahan masalah yang diambil contohnya dalam dunia pendidikan yang memainkan peran bagi kehidupan peserta didik.

Niederle \& Vesterlund (Wulandari, 2016) menyebutkan peserta didik perempuan memiliki gaya belajar yang bebas dibanding siswa laki-laki. Perbedaan itulah yang mendasari pola belajar peserta didik perempuan yang lebih bervariasi sehingga memungkinkan adanya kolaborasi atau kerja sama dan interaksi di dalam kelas. Sedangkan peserta didik laki-laki lebih cenderung menyukai proses pembelajaran bersifat individual dan lebih menyenangi kompetisi.

Bonolken (2014) menyebutkan bahwa peserta didik laki-laki yang tidak berbakat menunjukkan fungsional matematika lebih baik dibandingkan peserta didik perempuan. Hal tersebut bermakna bahwa peserta didik laki-laki yang memiliki keterbatasan berpikir matematis lebih mampu menggunakan berbagai atribut matematika ke dalam pemecahan masalah dibandingkan peserta didik perempuan.

Sehingga peneliti mengusung untuk mengangkat judul penelitian tentang "Deskripsi Kompetensi Strategis Matematis Kelas VII Smp Negeri 1 Palopo Berdasarkan Gender".

\section{B. Metode Penelitian}

Penelitian adalah penelitian deskriptif dengan pendekatan kualitatif. Penelitian ini dipilih dengan alasan peneliti mendeskripsikan kompetensi strategis matematis siswa kelas VII SMP Negeri 1 Palopo berdasarkan gender. Penelitian kualitatif bermaksud untuk memahami fenomena tentang apa yang dialami oleh subjek penelitian misalnya perilaku, presepsi, tindakan dan lain-lain. Peneliti mengambil lokasi penelitian di SMP Negeri 1 Palopo, Jl. Andi Pangerang No. 2, 
Kota Palopo Provinsi Sulawesi Selatan. Waktu pelaksanaan penelitian pada semester genap tahun ajaran 2020/2021. Fokus penelitian ini adalah mendeskripsikan kompetensi strategis matematis siswa kelas VII SMP Negeri 1 Palopo berdasarkan gender yang didasarkan pada indikator kompetensi strategis matematis yang terdiri dari merumuskan, merepresntasikan, dan menyelesaikan masalah. Pengembangan tes pemilihan subjek bertujuan untuk memilih calon subjek penelitian yang kemudian dikategorikan berdasarkan gender. Dalam penyusunan tes pemilihan subjek penelitian, dilakukan langkah-langkah sebagai berikut: Membuat draf tes pemilihan subjek penelitian. Hal ini dimaksudkan untuk mengkategorikan calon subjek penelitian. Pertimbangan dalam membuat draf tes pemilihan subjek penelitian harus memenuhi: (1) syarat konstruksi masalah yakni: kalimat tidak menimbulkan penafsiran ganda, batasan yang diberikan cukup untuk memecahkan masalah, pertanyaan penelitian menggunakan kalimat tanya atau perintah, batasan masalah yang diberikan jelas dan berfungsi, (2) memenuhi syarat bahasa yaitu menggunkan bahasa yang sesuai dengan kaidah baik dan benar, pertanyaan penelitian yang komunikatif, pertanyaan penelitian menggunakan kalimat matematika yang benar, serta tidak menimbulkan penafsiran ganda. Validasi, konstruk dan isi oleh pakar. Validitas ini dimaksudkan untuk mengetahui: (1) apakah tes pemilihan subjek penelitian memenuhi konstruk masalah? Yang meliputi: kalimat tidak menimbulkan penafsiran ganda, batasan yang diberikan cukup untuk memecahkan masalah, pertanyaan penelitian yang menggunkan kalimat tanya atau perintah, batasan masalah yang diberikan jelas, (2) apakah tes pemilihan subjek penelitian memenuhi konstruk bahasa? Yang meliputi: menggunakan bahasa yang sesuai dengan kaidah baik dan benar, rumusan masalah yang komunikatif, rumusan masalah menggunakan kalimat matematika yang benar, serta tidak menimbulkan penafsiran ganda.

Subjek penelitian ini menetapkan subjek yang akan dipilih dalam penelitian. Banyaknya subjek penelitian yang akan dipilih ada 2 orang kemampuan tinggi masing-masing 1 perempuan dan 1 laki-laki. Instrumen penelitian adalah peneliti sendiri. Dalam hal ini peneliti merupakan perencana, pelaksana pengumpulan data, penganalisis, penafsiran data, dan menjadi pelapor hasil penelitian. Peneliti sebagai instrumen akan mempermudah menggali informasi yang menarik meliputi 
informasi lain dari yang lain (temuan-temuan yang menarik), yang tidak direncanakan sebelumnya, yang tidak terduga terlebih dahulu atau yang tidak lazim terjadi. Pada penelitian ini juga digunakan instrumen pendukung lainnya yaitu : (1) tes pemilihan subjek penelitian, (2) pedoman wawancara. Teknik pengumpulan data dalam penelitian ini dilakukan melalui wawancara berbasis tes menyelesaikan soal dimana siswa diberikan lembar kerja siswa, kemudian subjek diminta untuk menceritakan secara rinci pemahamannya dalam memecahkan masalah dari soal tersebut. Selanjutnya dilakukan observasi untuk menelusuri alasan melakukan keselahan tersebut dan kemungkinan-kemungkinan penyelesaian lain yang dapat dilakukan. Kemampuan subjek penelitian dipelajari melalui imterpresentasi yang dibeikan subjek dalam menjawab pertanyaan wawancara. Analisis data kualitatif merupakan proses berkelanjutan yang membutuhkan refleksi terus-menerus terhadap data, mengajukan pertanyaan-pertanyaan analisis dan menulis catatan singkat sepanjang penelitian (Creswell, 2012). Data yang telah dikumpulkan akan dianalisis dengan menggunakan analisis data nonstatistik karena penelitian ini merupakan penelitian kualitatif. Analisis dilakukan secara mendalam pada siswa tentang pemecahan masalah setelah siswa dikategorikan berdasarkan gendernya. Proses analisis data dimulai dengan menelaah seluruh data yang tersedia dari berbagai sumber, yaitu dari wawancara pengamatan yang sudah dituliskan dalam catatan lapangan, dokumen pribadi, dokumen resmi, gambar, foto, dan sebagainya (Moleong, 2011). Analisis data dilakukan terbatas pada apa yang dikerjakan siswa (baik secara lisan maupun tulisan).

\section{Hasil Peneltian Dan Pembahasan}

Hasil penelitian tentang deskripsi kompetensi strategis matematis siswa pada himpunan siswa kelas VII SMP Negeri 1 Palopo berdasarkan gender. Penentuan subjek dalam penelitian ini digunakan tes kompetensi strategis matematis dan pedoman wawancara. Selanjutnya, hasil tes kompetensi strategis matematis yang diperoleh dari siswa kelas VII A SMP Negeri 1 Palopo di analisis oleh peneliti untuk menentukan 2 orang siswa yang akan dijadikan subjek, subjek yang terpilih berdasarkan pencapaian nilai yang diperoleh yaitu siswa yang berkemampuan tinggi masing-masing 1 perempuan dan 1 laki-laki. 
Berdasarkan respon kedua subjek pada paparan hasil penelitian tersebut bahwa Subjek Berkemampuan Tinggi Gender Perempuan (SKTGP) dan Subjek Berkemampuan Tinggi Gender Laki-laki (SKTGL) mampu mencapai indikator merumuskan hingga memecahkan masalah, yang membedakan kedua subjek adalah cara kerja dalam menyelesaikan soal dan hasil akhir pada soal nomor 2, yang didapat kedua subjek pun berbeda. Respon subjek dalam menyelesaikan soal himpunan berdasarkan indikator kompetensi strategis matematis.

Hasil penelitian untuk Subjek Kemampuan Tinggi Gender Perempuan (SKTGP) dan Subjek Kemampuan Tinggi Gender Laki-laki (SKTGL) untuk tes kompetensi strategis matematis saat tes wawancara menunjukkan bahwa subjek SKTGP dan SKTGL memiliki kemampuan yang sama, tetapi pada soal nomor 2 Subjek Kemampuan Tinggi Gender Perempuan (SKTGP) memiliki jawaban yang kurang tepat sehingga subjek tidak memenuhi indikator kompetensi strategis matematis. Subjek Kemampuan Tinggi Gender Perempuan (SKTGP) berdasarkan tes kompetensi strategis matematis menunjukkan bahwa jawaban Subjek Kemampuan Tinggi Gender Perempuan (SKTGP) tidak lengkap sehingga tidak mampu dengan tepat memenuhi indikator kompetensi strategis matematis. Hal ini terjadi karena jawaban Subjek Kemampuan Tinggi Gender Perempuan (SKTGP) pada soal nomor 2 kurang tepat, dimulai dari indikator yaitu: pertama, subjek tidak tepat memenuhi indikator merumuskan hal ini terjadi karena subjek menuliskan apa saja yang diketahui dari soal nomor 2 tidak lengkap hanya beberapa yang dapat subjek tuliskan sehingga tidak dapat memenuhi indikator pertama yang akan berpengaruh pada indikator merepresentasikan dan memecahkan masalah, itulah sebabnya Subjek Kemampuan Tingi Gender Perempuan (SKTGP) dikatakan parsial atau tidak mencapai indikator kompetensi strategis matematis secara keseluruhan. Subjek Kemampuan Tinggi Gender Laki - Laki (SKTGL) berdasarkan tes kompetensi strategis matematis menunjukkan bahwa semua jawaban subjek dari soal nomor 1 sampai 3 lengkap dan benar serta memenuhi semua indikator kompetensi strategis matematis, sehingga Subjek Kemampuan Tinggi Gender Laki - Laki dikatakan lengkap karena telah memenuhi secara keseluruhan indikator kompetensi strategis matematis yaitu: (1) merumuskan, (2) merepresentasikan, dan (3) memecahkan masalah. 
Berdasarkan hasil penelitian dalam pembelajaran matematika, Kilpatrick, Swafford, \& Findell (2001) menyatakan bahwa kompetensi strategis (strategic competence) merupakan suatu kemampuan untuk merumuskan, merepresentasikan, serta menyelesaikan permasalahan matematika.

Indikator kompetensi strategis matematis harus dimiliki dan dikuasai siswa agar siswa dapat menyelesaikan masalah matematika dengan baik. Menurut Kilpatrick, Swafford, dan Findell (Afrilianto, 2012), indikator kompetensi strategis yaitu: (1) memahami situasi serta kondisi dari suatu permasalahan, (2) menemukan kata-kata kunci serta mengabaikan hal-hal yang tidak relevan, (3) menyajikan masalah secara matematik dalam berbagai bentuk, (4) memilih penyajian yang cocok untuk membantu memecahkan masalah, (5) memilih metode penyelesaian yang efektif dalam menyelesaikan suatu permasalahan, dan (6) menemukan solusi dari permasalahan yang diberikan.

Nursopiah, dkk (2014) menyatakan bahwa kompetensi strategis matematis merupakan kemampuan untuk merumuskan, merepresentasikan dan memecahkan masalah matematika (Kilpatrick, Swafford, dan Findell, 2001). Pertama merumuskan, siswa dapat memahami dan memilih informasi yang relevan, merumuskan informasi yang didapat serta menyusun strategi yang harus dilakukan dalam menyelesaikan suatu permasalahan. Kedua merepresentasikan, siswa dapat menyajikan masalah tersebut kedalam model matematika melalui kata-kata, notasi, simbol, tabel, atau grafik. Ketiga menyelesaikan masalah matematika, siswa mampu memilih serta mengembangkan metode yang tepat dalam menyelesaikan masalah matematika, dapat menemukan solusi dari permasalahan yang diberikan dan mampu menafsirkan jawaban dari permasalahan matematika tersebut. Proses belajar melalui kompetensi strategis matematis bertolak pandangan bahwa siswa sebagai subjek dan objek dalam belajar yang mempunyai kemampuan untuk memecahkan masalah mereka sehingga siswa termotivasi untuk belajar keras. Kompetensi strategis matematis sebagai suatu usaha mencari jalan keluar dari suatu kesulitan guna mencapai suatu tujuan yang tidah begitu mudah segera dapat dicapai dan menggaris bawahi bahwa "untuk kompetensi strategis matematis siswa yang berhasil selalu disertakan upaya-upaya khusus yang dihubungkan dengan jenis jenis persoalan sendiri serta pertimbangan-pertimbangan mengenai isi yang 
dimaksud". Konsep-konsep dan aturan-aturan harus sintesis menjadi bentuk-bentuk kompleks yang baru agar siswa dapat menghadapi situasi-situasi masalah yang baru, jadi kompetensi strategis matematis adalah kemampuan peserta didik untuk menyelesaikan pertanyaan yang menantang yang tidak dapat dipecahkan oleh prosedur rutin yang sudah diketahui peserta didik.

\section{Kesimpulan}

Berdasarkan hasil penelitian dan pembahasan yang dilakukan pada Bab IV maka disimpulkan sebagai berikut:

1. Kompetensi Strategis Matematis siswa subjek kemampuan tinggi gender perempuan (SKTGP) dalam menyelesaikan soal himpunan menunjukkan bahwa subjek SKTGP mampu mengerjakan dan menyelesaikan soal sesuai prosedur pengerjaan soal. Tes kompetensi strategis matematis mempunyai indicator yaitu : (a) merumuskan, (b) merepresentasikan, dan (c) memecahkan masalah, dari hasil tes kompetensi strategis matematis menunjukkan subjek SKTGP mampu mencapai indicator kompetensi strategis matematis untuk soal nomor 1 dan 3, sedangkan untuk soal nomor 2 subjek SKTGP tidak mampu memenuhi dengan tepat indikator kompetensi strategis matematis.

2. Kompetensi strategis matematis siswa subjek kemampuan tinggi gender lakilaki (SKTGL) dalam menyelesaikan soal himpunan menunjukkan bahwa subjek SKTGL mampu mengerjakan dan menyelesaikan soal sesuai prosedur pengerjaan soal. Tes kompetensi strategis matematis mempunyai indicator yaitu : (a) merumuskan, (b) merepresentasikan, dan (c) memecahkan masalah, dari hasil tes kompetensi strategis matematis menunjukkan subjek SKTGL mampu mencapai indicator kompetensi strategis matematis untuk soal nomor 1,2 , dan 3 . 


\section{Daftar Pustaka}

Al, Kilpatrick. e. (2001). Helping Childrem Learn Mathematics. Washington DC: National Research Council.

Gazali, R. Y. 2016. Pembelajaran Matematika yang Bermakna. Jurnal Pendidikan Matematika 2(3), 181-190.

Hoang, T. N. 2008 "The Effects Of Grade Level, Gender and Ethnicity On Attitude and Learning Exprerimences of Girls and Boys". ISSN : Journal of Research on Technology in education / volume 41 Issue 3 Hal : 253 - 276

Nursopiah, D, dkk. 2014. Pengaruh Penerapan Strategi Pembelajaran Giving Question And Getting Answer Terhadap Peningkatankompetensi Strategis Matematis Pada Siswa SMK. Educare, Vol 12, No. 2.

Sudarsana, I. K. 2016. Pemikiran tokoh pendidikan dalam buku lifelong learning: policies, practices, and programs (Perspektif Peningkatan Mutu Pendidikan di Indonesia). Jurnal Penjaminan Mutu, 2(2), 44-53.

Widjajanti, D. B. 2009. Kemampuan pemecahan masalah matematis mahasiswa calon guru matematika: apa dan bagaimana mengembangkannya. In Seminar Nasional Matematika dan Pendidikan Matematika (Vol. 5). 